\title{
Are Certifications Necessary to Join the C-Suite?
}

\author{
Passard Dean \\ IMA's Committee on Academic Relations \\ Professor of Accounting \& Finance \\ Donald R. Tapia College of Business \\ Saint Leo University Saint Leo, FL 33574, USA \\ Kelsey Bare \\ Donald R. Tapia College of Business \\ Saint Leo University Saint Leo, FL 33574, USA \\ Timothy Wiseman \\ Assistant Professor of Accounting \\ Donald R. Tapia College of Business \\ Saint Leo University Saint Leo, FL 33574, USA
}

\begin{abstract}
Much research has been done on the importance of certifications, revealing that they are not only beneficial to individuals and companies, but also to educational communities. The question is, is it necessary for accountants and other financial professionals to have a professional certification, such as the CPA or the CMA, to elevate to the level of senior management in major corporations? To research this question, a list of the Fortune 500 companies was retrieved from the Internet and a review of the qualifications of the top executives was performed. The results were very interesting and are presented below.
\end{abstract}

Keywords: Certifications; Financial Professionals; Designation; Accountants; Management

\section{Introduction}

Professional accounting certifications have been around since 1896 when Governor Levi P. Morton of New York signed the first certified public accountant (CPA) bill into law. Since then other certifications have become common place. These include, but are not limited to, the certified management accountant (CMA), the certified internal auditor (CIA), and the certified fraud examiner (CFE) certifications.

In most, if not all, accounting programs, professors tend to strongly recommend students to sit for at least one certification to help themselves become more marketable and also to help them progress more rapidly into senior management. As such, many accounting programs are geared towards preparing accounting majors to sit for the CPA exams. In more recent years, with the endorsement program offered by the Institute of Management Accountants (IMA), some accounting programs have been focusing on preparing their students to sit for both the CPA and CMA certification exams. In this article, the authors performed research to determine if becoming certified was a necessity for those who desire to progress into senior management.

\section{Importance of Professional Certifications}

Many in academe and the financial world believe that earning accounting and/or other financial certifications is a significant step in the right direction to advance one's career as a financial professional, especially for those who seek to elevate their careers to the senior management level. This is because many see professional certifications as an assurance of one's skills and competence. Some hold the view that while it is possible to elevate your career in certain companies without a certification, it is almost impossible to break into the roles of controller or chief financial officer (CFO) without a CPA license. While we may not all agree that a CPA is required to becoming a controller or CFO, we can agree that having a certification in your field of study can only help in your career. As such, it is recommended that accountants and other financial professionals who choose not to become CPAs, pursue other certifications, such as the CMA, CIA, CFE, etc. "The CMA certificate provides companies with an independent and standardized measure of 
competency" (Kreuze \& Newell, 1996, p. 334). It is also believed that the CMA designation is a good way to shorten the length of time to promotion to higher levels of management and increase compensation (Hrisak, 1992).

\section{Types of Certifications}

There are numerous certifications accountants and other financial professionals have available to them if they choose to get professionally certified. These include, the CPA, CMA, and CIA, which are the ones that readily come to mind, but there are many others, as well.

Following is a table that presents information on some other certifications that accountants and other financial professionals may pursue. This table was reproduced from the article "Which Certification is Right for You?" published in the New Accountant in Spring 2018.

\section{Table I}

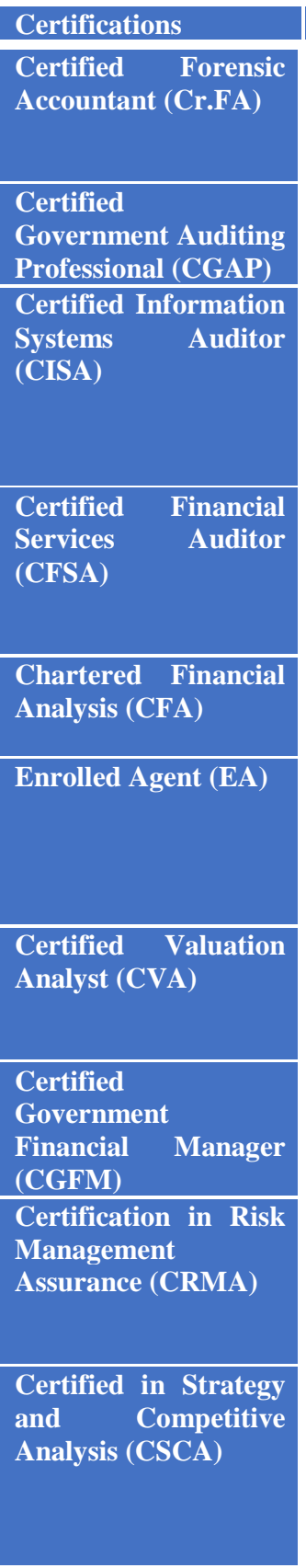

Description

The Cr.FA is for individuals pursuing a career in professional forensic accounting services. The requirements include having an active CPA license.

The CGAP is intended for audit professionals who work in the public sector, including federal, state, and local government.

The CISA is a globally recognized certification for information systems audit professionals with experience, knowledge, and skills in assessing vulnerabilities, report on compliance, and institute controls within enterprises.

The CFSA is a certification for audit professionals in the financial services industry, including banks, insurance companies, security and commodity services, and financial services regulatory agencies.

\section{The CFA certification is primarily for those} pursuing careers in finance and investment management.

The EA license is excellent for those who would like to represent both individuals and organizations before the IRS regarding matters of individual or business taxes. EAs are licensed by the federal government.

The CVA is designed for financial advisors who support business owners in understanding the value of their business.

The CGFM is a professional certification in governmental accounting, auditing, financial reporting, internal controls and budgeting at the federal, state and local levels.

The CRMA is designed for internal auditors and risk management professionals with responsibility for and experience in providing risk assurance, governance processes, quality assurance, or control self-assessment

The CSCA is one of the newest certifications available to financial professionals. It is primarily designed for CMAs. It complements and expands on the strategic planning and analysis skills assessed by the CMA certification.

\begin{tabular}{|c|c|}
\hline Granted by & Website \\
\hline $\begin{array}{l}\text { American Board of } \\
\text { Forensic Accounting } \\
(\text { ABFA) }\end{array}$ & $\underline{\text { www.abfa.us }}$ \\
\hline $\begin{array}{l}\text { Institute of Internal } \\
\text { Auditors (IIA) }\end{array}$ & www.theiia.org \\
\hline $\begin{array}{l}\text { Information Systems } \\
\text { Audit and Control } \\
\text { Association (ISACA) }\end{array}$ & www.isaca.org \\
\hline $\begin{array}{l}\text { Institute of Internal } \\
\text { Auditors (IIA) }\end{array}$ & www.theiia.org \\
\hline The CFA Institute & www.cfainstitute.org \\
\hline $\begin{array}{l}\text { National Association } \\
\text { of Enrolled Agents } \\
\text { (NAEA) }\end{array}$ & www.naea.org \\
\hline $\begin{array}{lr}\text { National } & \text { Association } \\
\text { of Certified } & \text { Valuators } \\
\text { and } & \text { Analysts } \\
\text { (NACVA) } & \end{array}$ & www.nacva.com \\
\hline $\begin{array}{l}\text { Association of } \\
\text { Government } \\
\text { Accountants (AGA) }\end{array}$ & www.agacgfm.org \\
\hline $\begin{array}{l}\text { Institute of Internal } \\
\text { Auditors }\end{array}$ & www.theiia.org \\
\hline $\begin{array}{l}\text { Institute of } \\
\text { Management } \\
\text { Accountants }\end{array}$ & www.imanet.org \\
\hline
\end{tabular}

Source: Table reproduced from the New Accountant (Spring 2018) with authors' permission 
The Certified Public Accountant (CPA) license is possibly the mostwell-known designation in the world(Dean, Dean \& Dean, 2018). "With this accounting certification, you validate your expertise in forensic accounting, tax, compliance, risk management and other skills that can lead to top CPA jobs" (Robert Half, 2019). Some have proclaimed it the "gold standard" of designations though many outside the accounting and finance fields have no idea what the CPA designation means. That said, if you say you are a CPA, the term is recognized immediately(Dean, Dean \& Dean, 2018). However, more than just being readily recognized, having a CPA license is beneficial to all accountants in various ways. Additionally, though many jobs require other designations, having a CPA license sends the message that you have attained a high level of excellence and expertise. Furthermore, having earned the CPA license will increase your marketability as a financial professional(Dean, Dean \& Dean, 2018). It is of paramount importance to note that only accountants with CPA licenses have the authority to write audit reports and express opinions on the financials of publicly traded companies. Just as important, it is imperative to know that while accountants with CPA licenses can perform the duties that other accountants do, the CPA license is not as specific as other accounting and financial certifications.

"The Certified Management Accountant (CMA) certification is another excellent designation for accountants and other financial professionals" (Dean, Dean \& Dean, 2018, p. 15). "Professionals who hold this accounting certification demonstrate mastery of critical accounting and financial management skills from a generalized, managerial and internal perspective" (Robert Half, 2019). "There are two parts to the CMA exam. Part 1 focuses on financial reporting, planning, performance, and control. Part 2 focuses on financial decision making" (Dean, Dean \& Dean, 2018, p. 15). We could say the CMA certification focuses on both the "what" and the "why" thereby helping management with both operational and strategic decision making (Dean, Dean \& Dean, 2018). This certification is useful to all accountants and other financial professionals who seek to understand business both operationally and strategically. You could say that the CMA certification helps to prepare individuals for executive leadership roles in corporations. The CMA certification is considered a more practical application of the theoretical concepts tested in the CPA exams and is recommended for those in the corporate sector, particularly in large, multinational companies(Robert Half, 2019).

"Another important designation is the Certified Internal Auditor (CIA) certification. It is the only global certification for internal auditors" (Dean, Dean \& Dean, 2018, p. 20). The CIA certification is indicative of a significant level of competence and is perceived to provide career advantages in internal audit positions. This certification is primarily for those who are or are planning to pursue a career as internal auditors and also for individuals in compliance roles.The CIA certification is the only internationally accepted designation for the internal auditor career path. Additionally, individuals who hold this certification demonstrate competence in areas such as risk and control and information technology, as well as proficiency in working with internal staff and external clients (Robert Half, 2019).

As indicated in TABLE I, there are other certifications available to accountants and other financial professionals. Many of these certifications have not been identified in this paper. One that is listed in the aforementioned table that is important to mention is the Chartered Financial Analyst (CFA) certification. This certification is primarily for those financial professionals with a desire to work in the finance and investment environments. The CFA certification demonstrates knowledge and competence relating to principles of portfolio management, investment analysis, economics, and professional and ethical standards (Robert Half, 2019). While this certification may not be as wellknown as the CPA and CMA certifications, it is also an international certification.

\section{Methodology}

Certifications are available to professionals in almost, if not, every industry. One reason professional certifications have found their place in many industries is because they assist in advancing the profession. Additionally, professional certifications help employers to differentiate between potential employees, evaluate current employees and encourage them to improve their knowledge and skills. Professional certifications also help individuals to attain required skills for specific jobs as they tend to focus on skills and knowledge on a practical level. Some professional certifications may help to build leadership and management skills. With this in mind, the authors performed research on the Fortune 500 companies to determine if it is a necessity for employees to be certified to elevate their careers to the senior management level in these organizations.

To accomplish this, a list of the most current companies comprising the Fortune 500 was retrieved in August of 2018. An analysis was performed to determine if the most senior executives had one or more certifications. The qualifications and position titles of the top three executives listed on each company's website were reviewed. The job titles identified were the Chief Executive Officer (CEO), Chief Financial Officer (CFO), Chief Operating Officer (COO), President, Chief Information Officer (CIO), Chairman, Senior Vice President, Vice President, Chief Commercial Officer (CCO), 
Chief Audit Executive (CAE), Controller, Chief Accounting Officer (CAO), Chief Administrative Officer, Chief Risk Officer, Treasurer, Corporate Secretary.

After this determination was made based on the information on the websites, the certifications held by individuals with the aforementioned titles were reviewed. Some websites did not reveal the information so further research was required using LinkedIn and accessing executive profiles in order to find their certifications. Once the information from the company's websites and LinkedIn were found regarding the certifications, the information was recorded in an Excel spreadsheet for analysis.

\section{Results}

After reviewing the information gathered in the research it was apparent that many individuals in top executive positions did not hold any certifications. Of the 1,497 executives whose profiles were reviewed only 362 or $24.2 \%$ of them held certifications. Additionally, only 269 companies or 53.85 of the Fortune 500 companies had an executive with at least one certification. Most individuals who held the title of CEO did not have a certification. In fact, of the 500 CEOs only 46 or $9.2 \%$ had a certification. It was evident in the research performed that numerous individuals in senior level positions did not hold any certification. Another finding is that executives in the oil industry were licensed engineers and most individuals in accounting positions had certifications. Those certifications that were held included CPA, CFA, chartered accountant, as well as other certifications related to the accounting or financial field. Of the 485 CFOs, 191 or $39.3 \%$ had certifications. Additionally, of the 485 CFOs, 159 or $32.8 \%$ had CPA licenses. It is important to note that the most popular certification was the CPA, which represented 283 or $78.2 \%$ of the 362 total certifications held by Fortune 500 executives.

\section{Conclusion}

This research indicates that, while it is certainly not essential for managers wishing to ultimately enter the $\mathrm{C}$ suite to have a certification, there is at least some evidence that, at least with respect to the CFO position, the possession of a certification, particularly the CPA designation, may well be beneficial. Although the majority of top officers did not possess certification, almost one-third of CFOs had, in fact, earned the CPA certificate, and another 32 CFOs held another certification. This would seem to indicate that earning a certificate will not be a prerequisite for attaining $\mathrm{C}$ suite status, even as a CFO. While the possession of a certificate could be a factor when candidates are closely matched in other areas, such certification may not override a candidate who has demonstrated strong performance. As a practical matter, it would seem that, for those seeking promotion to high levels within corporations, having more qualifications that could be pointed to would be a benefit, but not a necessity.

\section{References:}

10 Totally Random But Interesting Facts About Accounting https://nasba.org/app/uploads/2017/07/InfographicAccounting-Facts.pdf - retrieved 12/13/2018

Dean, P.C.,Dean, P.M., and Dean, J. (2018). Which Certification is Right for You?, New Accountant, Spring 2018, Issue \#1776, 14-15, 20.

Gramling, A and Myers, P. (1997). Practitioners' and Users' Perceptions of the Benefits of Certification of Internal Auditors, Accounting Horizon, March, 39-53.

Hrisak, D. (1992). Interviews with original CMAs. Management Accounting, April, 34-37.

Kreuze, J. G. and Newell, G. E. (1996). A strategy for improving the quality of entry-level management accountants Journal of Education for Business, Jul/Aug, 334-338.

Robert Half, (February 2019). Accounting Certifications Employers Really Want to See, https://www.roberthalf.com/blog/salaries-and-skills/finance-and-accounting-certifications-employers-want-tosee - retrieved March 11, 2019

Tysiac, K. (2012). Test your CPA history knowledge. Journal of Accountancy, 213(6), 42-49. 